\title{
Publicações do Serviço de Documentação do D.A.S.P.
}

\section{OBRAS EDITADAS A PARTIR DE 1965}

Circulares da Presidência da República - de 1962 a 1963.

Circulares da Presidência da República — de 1964.

Promoçãa e Adesso - Decreto números 53.480 e 54.488 , ambos de 1964.

Prontuário de Redação Oficial - João Luiz Ney - 4* edição.

História Administrativa do Brasil -. Volume I - Hélio de Alcântara Avellar e Alfredo D'Escragnolle Taunay $-2^{*}$ edição.

Estatuto dos Funcionários Civis da União e Legislação Regulamentadora - Lei $\mathrm{n}^{\circ} 1.711$ de 28 de outubro de 1952.

Regimento do D. A. S. P. - Aprovado pelo Decreto $\mathrm{n}^{\circ} 50.679$, de 31 de maio de 1961 - 3* edição.

O Departamento de Referência - Tradução de Sylvio do Valle Amara] (Charles F. MoCombs) - $4^{*}$ edição.

Enquadtamento e Readaptação - Pareceres da Comissão de Classifica. ção de Cargos - Waldyr dos Santos.

Noções Básicas de Análise - João Luiz Ney.

Formação Profissional: Fórmulas Ideais - Estanislau Fischlowitz.

Manual de Serviço dos Processos das Pensões Civis do Tesouro Nacional
- Série Manuais de Serviço Wanderley T. Viana e Olavo P. Pinto.

$D$.A. S. P. - Organização funcional e localização de órgãos sediados na Capital Federal e dos Representantes nos Estados (Nomes, Endereços e Telefones).

Órgãos da Administração Federal (Arrolamentos e subordinação, incluindo: Interpol, Poder Legislativo e Poder Judiciário).

Promoção, Acesso, Transferência e Remoção dos Funcionários Públicos Civis da União - Decretos números 53.480 de 23-1-964; 54.488. de 15-10-64 e 53.481, de 23-1-964.

Circular $n^{\circ} 18$ - Secretaria da Presidência da República. Seção de Publicações do Serviço de Documentação do DASP - 1965.

Circulares da Presidência da República - de 1959 a 1964.

Lei $n^{\circ} 4.345$ de 26-6-964 - Institui novos valôres para os vencimentos dos servidores públicos civis do Poder Executivo e dá outras providências.

Lei $\pi^{\circ} 4.348$ de 26-6-964 - Estabelece normas processuais relativas a Mandado de Segurança.

Lei $n^{\circ} 4.863$ de 29-11-965 - Reajusta os vencimentos dos servidores civis e militares, altera as aliquotas dos impostos de renda, importa- 
ção. Consumo e Sêlo e da cota de previdência social, unifica contribuições baseadas nas fôlhas de salários, e dá outras providências.

Lei $n^{\circ} 4.863$ de 29-11-965 - Tabelas de Vencimentos dos Servido:es I'úblicos Federais civis e militares, dos membros do Ḿinistério Públicu Federal e Serviço Juridico da União, inclusive cotas de SalárioFamilia, e ainda, tabelas de Funções Gratificadas e Cargos em Comissão - D. O. de 30-11-65 Suplemento $\mathrm{n}^{\circ} 228$.

Lei $n^{\circ}$ 1, de 13-11-963 - Institui o Cruzeiro Nôvo e dá outras providências.

Decretos $n^{\text {s }} 54.061$ de 28-7-964 Regulamenta o Regime de Tempo Integral previsto nos arts. $11 \mathrm{e}$ 12 da Lei $\mathrm{n}^{\circ} 4.345$ de 26-6-964 e Decreto $n^{\circ} 56.730$ de 16-8-965 - Altera o decreto anterior D. O. de 17-8-965.

Decreto $n^{\circ} 56.887$ de 20-9-965 - $\mathrm{Al}_{1}$. tera o Regimento da Comissão de Classificação de Carges. - D.O. de 23-9-965 - Seção I.

Lei $n^{\circ}$ 881-A de 6-12-965 - Dispõe sôbre o Estatuto do Magistério Superior - D. O. de 10-12-965.

Decreto $n^{\circ} 57.630$ de 14-1-66 - Dispõe sôbre Nomeação e Admissão de Pessoal para o Serviço Público Federal - D. O. de 17-11-966.

Decreto $\pi^{\circ} 57.744$ de 3-2-966 - Regulamenta o Regime de Tempo In- tegral e Dedicação Exclusiva D. O. de 17-2-966.

Decreto $n^{\circ} 58.095$ de 28-3-966 Aprova o Regimento da Comissão de Tempo Integral e Dedicação Exclusiva $-D$. O. de 1-4-966.

Exposição de Motivos $n^{\circ}$ GB-25, de 1-4-966 - Normas e c:itérios elaborados pela COTIDE para aferição da essencialidade, complexidade e grau de responsabilidade de atribuições, e para investigação das condições do mercado de trabaiho e conseqüentes dificuldades de recrutamento para determinados c.trgos.

Indice da Revista do Serviço Público do Ano XXIV - 1961.

Circulares da Presidência da República - Expedidas em 1965.

Estudos de Direito Administrativo Vol. II - Pareceres - Clenicio da Silva Duarte.

O Serviço de Revisão de Provas Tipográticas - 2* edição - Francisco Wlasek Filho.

Municipio e Municipalização - $1^{*}$ edição - Manoel de Oliveira Franco Sobrinho.

Censo dos Servidores públicos Civis da União e das Autarquias - Decreto $\mathrm{n}^{2} 58.297$ de 2-5-966 - Fstabelece normas para execução do censo dos servidores civis da União e das Autarquias. 